\title{
Genotoxic Evaluation of Surfactin C in Chinese Hamster Lung Cell Line
}

\author{
Jong Hwan Lim', In Bae Song 2 , Byung Kwon Park ${ }^{3}$ Myoung Seok Kim², \\ Youn-Hwan Hwang ${ }^{2}$ and Hyo In Yun ${ }^{2}$ \\ ${ }^{1} B \& C$ Biopharm, Suwon 443-270, \\ ${ }^{2}$ Institute of Veterinary Animal Science, Chungnam National University, Daejeon 305-764, Korea \\ ${ }^{3}$ JEONJIN BIO, Daegu 704-230, Korea
}

(Received January 31, 2009; Revised February 9, 2009; Accepted February 18, 2009)

\begin{abstract}
To investigate the mutation inducibility of surfactin $\mathrm{C}$, we performed the chromosome aberration assay with Chinese hamster lung cells in vitro. The colorimetric MTT screening assay was carried out to determine the cytotoxicity index $\left(\mathrm{IC}_{50}\right)$ of surfactin $\mathrm{C}$. The $\mathrm{IC}_{50}$ value was $125 \mu \mathrm{g} / \mathrm{ml}$. For the chromosome aberration test of surfactin C, the maximum concentration was employed as $125 \mu \mathrm{g} / \mathrm{ml}$, followed by 62.5 and $31.25 \mu \mathrm{g} / \mathrm{ml}$ for the lower concentrations, with or without metabolic activation (S9). Cyclophosphamide and mitomycin C were used as positive controls in the presence and absence of S9 metabolic activation, respectively. These results showed that surfactin C was not capable of inducing chromosome aberration, as measured by the chromosome aberration test using Chinese hamster lung cell line. There is no evidence for surfactin $C$ to have a genotoxic potential.
\end{abstract}

Key words: Surfactin C, Chromosome aberration test, MTT test, Chinese Hamster Cell

\section{INTRODUCTION}

Biosurfactants are proteins with detergent, emulsifier, and antimicrobial actions that have potential application in environmental applications such as the treatment of organic pollutants and oil recovery (Georgiou et al., 1990; Desai and Banat, 1997; Banat et al., 2000; Rodrigues et al., 2006). Especially, microbial surfactants have several advantages over synthetic surfactants such as lower toxicity, easier biodegradability, better environmental compatibility, higher selectivity and specific activity at extreme temperatures, $\mathrm{pH}$ and salinity (Georgiou et al., 1990; Desai and Banat, 1997; Banat et al., 2000; Rodrigues et al., 2006).

Surfactin showed that it had a strong surface tension-lowering activity and showed antiviral, antitumor, fibrinolytic and hypocholesterolemic activities (Arima et

Correspondence to: Jong-Hwan Lim, B\&C Biopharm, Advanced Institutes of Convergence Technology, 906-5 luidong, Yeongtonggu, Suwonsi, Gyeonggido 443-270, Korea E-mail: jhlim99@empal.com and Hyo-In Yun, Institute of Veterinary Animal Science, College of Veterinary Medicine, Chungnam National University, 220, Gungdong, Yuseonggu, Daejeon 305-764, Korea

E-mail: hiyun@cnu.ac.kr al., 1968; Singh and Cameotra, 2004; Mulligan, 2005). It is a mixture of isofoms which slightly differ in their physiological properties due to a variation in the chain length and branching of its hydroxy fatty acid component as well as substitutions of the amino acid components of the peptide ring (Kanatomo et al., 1995). Among of them, surfactin C (Fig. 1) enhanced endogenous thrombolytic reactions by activation of plasminogen activator and inhibition of platelet aggregation (Kikuch and Hasumi, 2002; Lim et al., 2005). It showed antimicrobial activity against methicillin-resis-

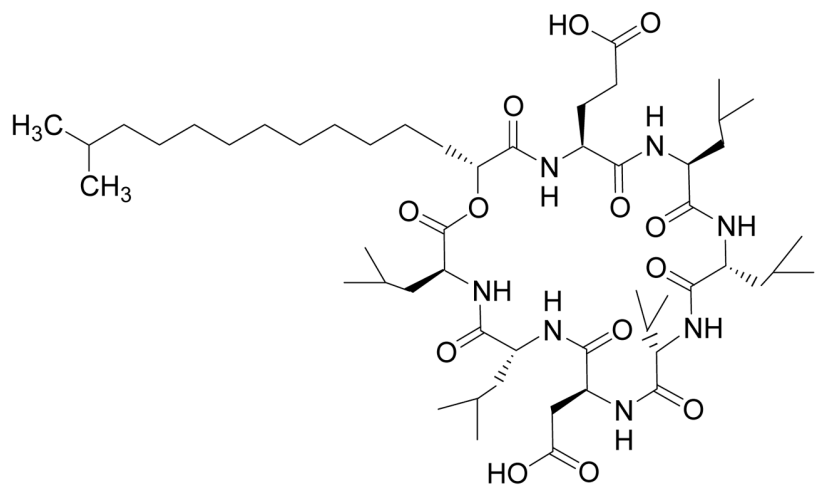

Fig. 1. The structure of surfactin $\mathrm{C}$. 
tant Staphylococcus aureus (MRSA) and inhibited various inflammatory mediators such as cyclooxygenase2 , interleukin- $1 \beta$ and inducible nitric oxide synthase (Hwang et al., 2005a, b; Takahashi et al., 2006). Moreover, it was less toxic than other surfactants as judged from the results of an acute toxicity study in mice (Pakr et al., 2006). Hwang et al. (2008) demonstrated that it showed no genetic toxicity in bacterial reverse mutation and mouse micronucleus assay. The chromosome aberration test using cultured mammalian cells is one of the sensitive methods to predict environmental mutagens and/or carcinogens and is a complementary test to the bacterial reverse mutation test. There is no literature about the genetic toxicity of surfactin $C$ in mammalian cell lines. Therefore, we tested its clastogenicity in cultured mammalian cells, Chinese hamster lung $(\mathrm{CHL})$ cells.

\section{MATERIALS AND METHODS}

Chemicals. Surfactin C (purity $>98 \%$ ) produced from Bacillus subtilis BC1212 was kindly obtained from B\&C Biopharm (Suwon, Korea). Cyclophosphamide (Sigma, USA) and mitomycin C (Singm, USA) were served as positive controls. Rat liver S9 induced with Aroclor 1254 (Moltox Inc, USA) was used for metabolic activation.

Chinese hamster lung (CHL) cell line. CHL cells were purchased from the American Type Culture Collection (ATCC, USA) and cultured in Eagle's minimal essential medium (EMEM, Hyclone, USA), supplemented with $10 \%$ fetal bovine serum (FBS, Hyclone, USA), in a $37^{\circ} \mathrm{C}$ incubator containing $5 \% \mathrm{CO}_{2}$ without any antibiotics or anti-mycotics. Subcultures were carried out every 2 days, using $0.03 \%$ Puck's EDTA and $0.25 \%$ TrypsinEDTA solutions.

MTT assay. Cytotoxicity assay was performed using a two-fold serial dilution gradient of surfactin $\mathrm{C}$ concentrations, ranging from $15.6 \sim 1000 \mu \mathrm{g} / \mathrm{mL}$. All treatments were performed in triplicate and the cells were cultured for $18 \mathrm{~h}$ in the presence and absence of surfactin C. An IC $\mathrm{C}_{50}$ concentration was determined from each of the three experiments and the final $\mathrm{IC}_{50}$ was determined by averaging the values of the three experiments $( \pm S D)$. The $I C_{50}$ is defined as the cytotoxicity index that reduces the cell number (by growth inhibition and/or cell killing) to $50 \%$ compared with untreatedcontrol $\mathrm{CHL}$ cells. The $\mathrm{IC}_{50}$ value was used to determine the chromosomal aberration assay concentration ranges.
Chromosomal aberration assay. The assay was performed according to OECD and scientific guidelines (Galloway et al., 1994; OECD, 1997). For the shortperiod assay with or without S9 mix, CHL cells $\left(2 \times 10^{5}\right.$ cells $/ 0.5 \mathrm{ml}$ ) were seeded in a 24 well plate culture dish, and incubated in a culture medium for overnight. The surfactin $\mathrm{C}$ was added with or without S9 mix and the cultures were incubated for $6 \mathrm{hr}$. After the $6 \mathrm{hr}$ treatment, the cells were washed with phosphate buffered saline (PBS), and incubated in fresh culture medium for a further $18 \mathrm{~h}$. The continuous treatment test was carried out for $24 \mathrm{~h}$ treatment without S9 mix. PBS was used as a negative control, while $20 \mu \mathrm{g} / \mathrm{ml}$ cyclophosphamide (Sigma, USA) and $0.1 \mu \mathrm{g} / \mathrm{ml}$ mitomycin C (Sigma, USA) were used as positive controls for experiments conducted with and without metabolic activation, respectively (Galloway et al., 1994). The cells were treated with colchicine (Sigma, USA; $0.1 \mu \mathrm{M}$ of final concentration) $2 \mathrm{~h}$ before cell harvesting. The cells were trypsinized and incubated in a $75 \mathrm{mM}$ hypotonic $\mathrm{KCl}$ solution for $20 \mathrm{~min}$ at $37^{\circ} \mathrm{C}$. Fixed with acetic acid-ethanol $(1: 3$ by volume), and then spread onto clean glass slides. Each slide was stained with $5 \%$ Giemsa solution.

Duplicate cultures were used for each experiment. Cells were harvested $24 \mathrm{~h}$ after treatment initiation and a minimum of 200 metaphases (100 from each of two duplicate cultures) were analyzed for chromosome damage. Aberrations were classified according to Scott et al. (1983) into chromosome and chromatid type damage, with further subdivision into deletions and exchanges. Polyploidy and endoreduplication were recorded as a percentage per 100 metaphases counted.

The frequencies of structural or numerical aberrations were evaluated by the following criteria; less than $5 \%, 5 \%$ to less than $10 \%$, and $10 \%$ or more were defined as negative (-), equivocal $( \pm)$ and positive (+), respectively. The result was considered to be positive if reproducibility was confirmed. Total frequencies of structural aberrations excluded the frequencies of aberrant cells that have gaps only without other aberrations.

Statistical analysis. Statistical analysis was performed using SPSS 12.0k. The differences in the frequency of chromosomal aberrations between groups treated with surfactin $C$ and controls were analyzed by the Fisher's exact test. $P$-values of less than 0.05 were considered to be consistent with statistical significance.

\section{RESULTS AND DISCUSSION}

Genotoxicity is the study of the toxic effects of chemical or physical substances to the gene pool, where 
Table 1. Summary of results obtained from chromosomal aberration test in $\mathrm{CHL}$ cells treated with $6 \mathrm{hr}$ short-treatments of surfactin $\mathrm{C}$

\begin{tabular}{|c|c|c|c|c|c|}
\hline \multirow{2}{*}{ Compound } & \multirow{2}{*}{$\begin{array}{l}\text { Conc. } \\
(\mu \mathrm{g} / \mathrm{ml})\end{array}$} & \multirow{2}{*}{ S9 mix } & \multirow{2}{*}{$\begin{array}{l}\text { Time } \\
(\mathrm{hr})^{1}\end{array}$} & \multicolumn{2}{|c|}{ Aberrated cell $(\%)^{2}$} \\
\hline & & & & $-g$ & $+g$ \\
\hline PBS & 0 & - & $6 / 18$ & 0 & 0 \\
\hline \multirow{3}{*}{ Surfactin C } & 125 & - & $6 / 18$ & 2 & 3 \\
\hline & 62.5 & - & $6 / 18$ & 1 & 2 \\
\hline & 31.25 & - & $6 / 18$ & 1 & 1 \\
\hline MMC & 0.1 & - & $6 / 18$ & $42^{*}$ & $44^{*}$ \\
\hline PBS & 0 & + & $6 / 18$ & 1 & 1 \\
\hline \multirow{3}{*}{ Surfactin C } & 125 & + & $6 / 18$ & 2 & 3 \\
\hline & 62.5 & + & $6 / 18$ & 2 & 2 \\
\hline & 31.25 & + & $6 / 18$ & 1 & 2 \\
\hline $\mathrm{CP}$ & 20 & + & $6 / 18$ & $54^{*}$ & $56^{*}$ \\
\hline
\end{tabular}

MMC, Mitomycin C; CP, Cyclophosphamide.

${ }^{1}$ Treatment time (exposure time/new medium time).

${ }^{2}-\mathrm{g}, \%$ of cells with chromosome aberrations; $+\mathrm{g}, \%$ of cells with chromosome aberrations $+\%$ of cells with gaps.

*Significantly greater than the corresponding vehicle control, $p<0.001$.

damages and/or changes to the genetic code or DNA sequence usually occur (Scott et al., 1983). Genotoxic insults may be studied by use of mutagenicity, carcinogenicity and/or teratogenicity assays, due to the close relationship of these three phenomena (Scott et al., 1983; O'Brien et al., 1996; Dearfield et al., 2002).

Chemicals that are not known to cause any chromatogenic aberration must first be tested for the evidence of cytotoxicity in the system chosen for genotoxicity testing (Scott et al., 1983). This would help the establishment of a maximum tolerated dose (MTD) of
Table 3. Summary of results obtained from chromosomal aberration test in CHL cells treated with $24 \mathrm{hr}$ shorttreatments of surfactin C

\begin{tabular}{cccccc}
\hline \hline Compound & $\begin{array}{c}\text { Conc. } \\
(\mu \mathrm{g} / \mathrm{ml})\end{array}$ & S9 mix & $\begin{array}{c}\text { Time } \\
(\mathrm{hr})^{1}\end{array}$ & & \multicolumn{2}{c}{ Aberrated cell (\%) } \\
\cline { 5 - 6 } & 0 & - & 24 & 1 & $+\mathrm{g}$ \\
\hline PBS & 0 & - & 24 & 2 & 3 \\
\hline \multirow{3}{*}{ Surfactin C } & 62.5 & - & 24 & 2 & 3 \\
& 31.25 & - & 24 & 2 & 2 \\
\hline MMC & 0.1 & - & 24 & $43^{*}$ & $45^{*}$ \\
\hline
\end{tabular}

MMC, Mitomycin C; CP, Cyclophosphamide.

${ }^{1}$ Treatment time (exposure time).

${ }^{2}-\mathrm{g}$, number or \% of cells with chromosome aberrations; $+\mathrm{g}$, number or $\%$ of cells with chromosome aberrations + number or $\%$ of cells with gaps.

*Significantly greater than the corresponding vehicle control, $p<0.001$.

the chemical being tested, as described above for the mitotic index assay. In our study, the MTT cytotoxicity assay was employed in determining the dose responses of surfactin $C$ directly without any metabolic activation. The $I C_{50}$ value of surfactin $C$ was found $125 \mu \mathrm{g} / \mathrm{ml}$.

To evaluate the genotoxic activities of surfactin $\mathrm{C}$, we carried out in vitro mutagenicity assays. The results obtained in the short-treatment assays for surfactin C with or without S9 mix were shown in Table 1 and 2. In the short-treatments with or without $\mathrm{S} 9 \mathrm{mix}$, the structural chromosomal aberrations and polyploidy rates were less than $5 \%$ for any concentration of the surfactin C. For the continuous treatments test, structural chromosomal aberrations and the polyploidy induction rates were less than $5 \%$ at any concentration in both

Table 2. Metaphase analysis of chromosomal aberration test in CHL cells treated with $6 \mathrm{hr}$ short-treatments of surfactin $\mathrm{C}$

\begin{tabular}{|c|c|c|c|c|c|c|c|c|c|c|c|c|c|}
\hline \multirow[b]{2}{*}{ Compound } & \multirow{2}{*}{$\begin{array}{l}\text { Conc. } \\
(\mu \mathrm{g} / \mathrm{ml})\end{array}$} & \multirow[b]{2}{*}{ S9 mix } & \multirow{2}{*}{$\begin{array}{l}\text { Time } \\
(\mathrm{hr})^{1}\end{array}$} & \multicolumn{10}{|c|}{ No. of structural aberration $(\%)^{2}$} \\
\hline & & & & ctb & $\operatorname{csb}$ & cte & cse & $\begin{array}{c}\text { Aberration } \\
\text { excluding gap (\%) }\end{array}$ & $\operatorname{ctg}$ & $\operatorname{csg}$ & pol & endo & $\begin{array}{c}\text { Aberration including } \\
\text { gap }(\%)\end{array}$ \\
\hline PBS & 0 & - & $6 / 18$ & 0 & 0 & 0 & 0 & 0 & 0 & 0 & 0 & 0 & 0 \\
\hline \multirow{3}{*}{ Surfactin C } & 125 & - & $6 / 18$ & 2 & 0 & 0 & 0 & 2 & 1 & 0 & 0 & 0 & 3 \\
\hline & 62.5 & - & $6 / 18$ & 1 & 0 & 0 & 0 & 1 & 1 & 0 & 0 & 0 & 2 \\
\hline & 31.25 & - & $6 / 18$ & 1 & 0 & 0 & 0 & 1 & 0 & 0 & 0 & 0 & 1 \\
\hline MMC & 0.1 & - & $6 / 18$ & 20 & 2 & 18 & 2 & 42 & 2 & 0 & 0 & 0 & 44 \\
\hline PBS & 0 & + & $6 / 18$ & 1 & 0 & 0 & 0 & 1 & 0 & 0 & 0 & 0 & 1 \\
\hline \multirow{3}{*}{ Surfactin C } & 125 & + & $6 / 18$ & 2 & 0 & 0 & 0 & 2 & 1 & 0 & 0 & 0 & 3 \\
\hline & 62.5 & + & $6 / 18$ & 1 & 0 & 1 & 0 & 2 & 0 & 0 & 0 & 0 & 2 \\
\hline & 31.25 & + & $6 / 18$ & 1 & 0 & 0 & 0 & 1 & 1 & 0 & 0 & 0 & 2 \\
\hline $\mathrm{CP}$ & 20 & + & $6 / 18$ & 25 & 5 & 22 & 2 & 54 & 2 & 0 & 0 & 0 & 56 \\
\hline
\end{tabular}

MMC, Mitomycin C; CP, Cyclophosphamide.

${ }^{1}$ Treatment time (exposure time/new medium time).

${ }^{2} \mathrm{ctb}$, chromatid break; csb, chromosome break; cte, chromatid exchange; cse, chromosome exchange; ctg, cromatid gap; csg, chromosome gap; pol, polyploidy; endo, endoredupication. 
Table 4. Metaphase analysis of chromosomal aberration test in $\mathrm{CHL}$ cells treated with $24 \mathrm{hr}$ short-treatments of surfactin $\mathrm{C}$

\begin{tabular}{|c|c|c|c|c|c|c|c|c|c|c|c|c|c|}
\hline \multirow[b]{2}{*}{ Compound } & \multirow{2}{*}{$\begin{array}{l}\text { Conc. } \\
(\mu \mathrm{g} / \mathrm{ml})\end{array}$} & \multirow[b]{2}{*}{ S9 mix } & \multirow{2}{*}{$\begin{array}{l}\text { Time } \\
(\mathrm{hr})^{1)}\end{array}$} & \multicolumn{10}{|c|}{ No. of structural aberration $(\%)^{2)}$} \\
\hline & & & & ctb & csb & cte & cse & $\begin{array}{c}\text { Aberration } \\
\text { excluding gap (\%) }\end{array}$ & $\operatorname{ctg}$ & $\operatorname{csg}$ & pol & endo & $\begin{array}{c}\text { Aberration } \\
\text { including gap (\%) }\end{array}$ \\
\hline PBS & 0 & - & 24 & 1 & 0 & 0 & 0 & 1 & 0 & 0 & 0 & 0 & 1 \\
\hline \multirow{3}{*}{ Surfactin C } & 125 & - & 24 & 2 & 0 & 0 & 0 & 2 & 1 & 0 & 0 & 0 & 3 \\
\hline & 62.5 & - & 24 & 2 & 0 & 0 & 0 & 2 & 1 & 0 & 0 & 0 & 3 \\
\hline & 31.25 & - & 24 & 1 & 0 & 1 & 0 & 2 & 0 & 0 & 0 & 0 & 2 \\
\hline MMC & 0.1 & - & 24 & 21 & 3 & 18 & 1 & 43 & 2 & 0 & 0 & 0 & 45 \\
\hline
\end{tabular}

MMC, Mitomycin C; CP, Cyclophosphamide.

${ }^{1}$ Treatment time (exposure time).

${ }^{2} \mathrm{ctb}$, chromatid break; csb, chromosome break; cte, chromatid exchange; cse, chromosome exchange; ctg, cromatid gap; csg, chromosome gap; pol, polyploidy; endo, endoredupication.

the $24 \mathrm{hr}$ (Table 3 and 4). Based on these data, surfactin $\mathrm{C}$ did not induced structural chromosomal aberrations in the short-treatments test and continuous treatment. The results suggested that surfactin $C$ has no clastogenic potential in cultured mammalian cells either with or without S9 activation. This is consistent with the previous reports that surfactin $C$ is negative with or without metabolic activation in mutation assay using Salmonella typhimurium and Escherichia coli (Hwang et al., 2008).

\section{REFERENCES}

Arima, K., Kakinuma, A. and Tamura, G. (1968). Surfactin, a crystalline peptidolipid surfactant produced by Bacillus subtilis: isolation, characterization and its inhibition of fibrin clot formation. Biochem. Res. Commun., 31, 488-494.

Banat, I.M., Makkar, R.S. and Cameotra, S.S. (2000). Potential commercial applications of microbial surfactants. Appl. Microbiol. Biotechnol., 53, 495-508.

Dearfield, K.L., Cimino, M.C., McCarroll, N.E., Mauer, I. and Valcovic, L.R. (2002). Genotoxicity risk assessment: a proposed classification strategy. Mutat. Res., 521, 121-135.

Desai, J.D. and Banat, I.M. (1997). Microbial production of surfactants and their commercial potential. Microbiol. Mol. Biol. Rev., 61, 47-64.

Galloway, S., Aardema, M., Ishidate, M., Ivett, J., Kirkland D., Morita, T., Mosesso, P. and Sofuni, T. (1994). Report from the working group on in vitro tests for chromosomal aberrations. Mutat. Res., 312, 241-262

Georgiou, G., Liu, S.C. and Sharma, M.M. (1990). Surface active compounds from microorganisms. Biotechnol., 10, 60-65.

Hwang, M.H., Lim, J.H., Kim, K.S., Rhee, M.H., Kim, N.W., Kim, J.C. and Park, S.C. (2005a). Antibacterial activity in vitro and primary dermal irritationtest in rabbits of surfactin produced in bacillus subtilus complex BC2121. J. Toxicol. Pub. Health, 20, 39-43.

Hwang, M.H., Lim, J.H., Yun, H.I., Rhee, M.H., Cho, J.Y., Hsu, W.H. and Park, S.C. (2005b). Surfactin C inhibits the lipopolysaccharide-induced transcription of interleukin-1 beta and inducible nitric oxide synthase and nitric oxide production in murine RAW 264.7 cells. Biotechnol Lett., 27, 1605-1608.
Hwang, Y.H., Park, B.K., Lim, J.H., Kim, M.S., Song, I.B., Park, S.C. and Yun, H.I. (2008). Evaluation of genetic and developmental toxicity of surfactin $C$ from Bacillus subtilis BC1212. J. Health Sci., 54, 101-106.

Kanatomo, S., Nagai, S., Ohki, K. and Yasuda, Y. (1995). Study on surfactin, a cyclic depsipeptide. I. Isolation and structure of eight surfuctin analogs produced by Bacillus natto KMD 2311. Yakugaku. Zasshi., 115, 756-764.

Kikuchi, T. and Hasumi, K. (2002). Enhancement of plasminogen activation surfactin $\mathrm{C}$ : augmentation of fibrinolysis in vitro and in vivo. Biochem. Biophys. Acta., 1596, 234-245.

Lim, J.H., Park, B.K., Kim, M.S., Hwang, M.H., Rhee, M.H., Park, S.C. and Yun, H.I. (2005). The anti-thrombotic activity of surfactins. J. Vet. Sci., 6, 353-355.

Mulligan, C.N. (2005). Environmental applications for biosurfactants. Environ Pollut., 133, 183-198.

O'Brien, P.J., Hales, B.F., Josephy, P.D., Castonguay, A., Yamazoe, Y. and Guengerich, F.P. (1996). Chemical carcinogenesis, mutagenesis and teratogenesis. Can. J. Physiol. Pharmacol., 74, 565-571.

Organization for Economic Cooperation and Development (OECD, 1997). Test Guideline 473, In vitro Mammalian chromosome aberration test. In: OECD Guidelines for the Testing of Chemicals. OECD Paris.

Park, B.K., Lim, J.H., Hwang, Y.H., Kim, M.S., Song, I.B., Lee, H.G., Han, S.J., Hwang, M.H., Kim, J.W., Park, S.C., Rhee, M.H. and Yun, H.I. (2006). Acute oral toxicity of surfactin C in mice. J. Toxicol. Pub. Health, 22, 453-458.

Rodrigues, L., Banat, I.M., Teixeira, J. and Oliveira, R. (2006). Biosurfactants: potential applications in medicine. J. Antimicrob. Chemother., 57, 609-618.

Singh, P. and Cameotra, S.S. (2004). Potential applications of microbial surfactants in biomedical sciences. Trends Biotechnol., 22, 142-146.

Scott, D., Danford, N., Dean, B., Kirkland, D. and Richardson C. (1983). In vitro chromosome aberration assays, Report of the UKEMS Sub-Committee on Guidelines for Mutagenicity Testing, Part 1, Cambridge University Press, Cambridge, UK, pp. 41-64.

Takahashi, T., Ohno, O., Ikeda, Y., Sawa, R., Homma, Y., Igarashi, M. and Umezawa, K. (2006). Inhibition of lipopolysaccharide activity by a bacterial cyclic lipopeptide surfactin. J. Antibiot (Tokyo), 59, 35-43. 